\title{
Stock Market Wealth and Consumer Spending
}

\author{
Martha Starr-McCluer \\ Federal Reserve Board of Governors
}

April 1998

\begin{abstract}
$\underline{\text { Abstract }}$
This paper investigates the effects of stock market wealth on consumer spending. Traditional macroeconometric models estimate that a dollar's increase in stock market wealth boosts consumer spending by 3-7 cents per year. With the substantial 1990s rise in stock prices, the nature and magnitude of this "wealth effect" have been much debated. After describing the issues and reviewing previous research, I present new evidence from the SRC Survey of Consumers. The survey results are broadly consistent with lifecycle saving and a modest wealth effect: Most stockholders reported no appreciable effect of stock prices on their saving or spending, but many mentioned "retirement saving" in explaining their behavior.

Please address correspondence to: Martha Starr-McCluer, Federal Reserve Board of Governors, Stop 153, Washington, D.C. 20551. Phone: (202) 452-3587. Fax: (202) 452-5295. Email: mstarr@frb.gov. I am grateful to Carol Bertaut, Chris Carroll, Dean Maki, and Maria Ward Otoo for valuable comments. The views expressed in this paper are those of the author, and not necessarily those of the Federal Reserve Board of Governors or its staff.
\end{abstract}




\section{Stock Market Wealth and Consumer Spending}

\section{Introduction}

The relationship between stock market wealth and consumer spending has been a subject of longstanding interest. Traditional macroeconometric models estimate that a dollar's increase in household wealth boosts consumer spending by 3 to 7 cents per year. Such an effect is consistent with predictions from a simple lifecycle model, in which consumers spend more over their lifetimes in response to higher wealth. However, the stock market is known to play a role as a passive predictor of information. Thus, it is also possible that stock prices simply lead aggregate economic activity, without any short-run change in spending induced by changes in wealth (Poterba and Samwick, 1995). Understanding the response of spending to changes in wealth is important for determining how stock market fluctuations affect the macroeconomy. The question also bears directly on theories of saving behavior, and on the issue of retirement preparedness by today's workers.

The experience of the past few years provides an interesting opportunity to revisit this issue. Stock prices increased substantially between 1994 and 1997, with the S\&P 500 more than doubling over this period. At the same time, stock ownership broadened considerably, mostly through mutual funds and retirement accounts, so that a large number of households likely experienced wealth gains. The increase in wealth might be expected to boost consumer spending and lower the saving rate, and indeed these trends occurred. However, it is hard to separate the influence of the "wealth effect" from other factors that also would have promoted spending, such as strong income growth and favorable labor market conditions.

This paper presents some new evidence on the response of spending to changes in wealth. The data come from the Michigan SRC Survey of Consumers, an ongoing, nationally representative survey of U.S. households. In interviews conducted between July and September 1997, households owning stock were asked special questions about their spending and saving. The questions covered a number of factors that may influence the effect of wealth on spending, including the value and form of stockholdings, stock price expectations, concerns about retirement, and perceptions of income uncertainty. In brief, the results are 
broadly consistent with lifecycle saving and a modest wealth effect: The vast majority of stockholders reported no appreciable effect of stock prices on their spending or saving, but many mentioned "retirement saving" in explaining their behavior.

The next section of this paper reviews previous research on the relationship between stock market wealth and consumer spending. The third section describes the data from the Michigan Survey, and the fourth presents the results. A final section summarizes and concludes.

\section{Background and previous research}

To frame the discussion, it is useful to review how an unexpected increased in wealth would affect consumption in a simple lifecycle model. Suppose the household has initial wealth of $A_{0}$. In each period, it earns labor income of $Y_{t}$, consumes $C_{t}$, and saves $S_{t}$. The rate of return to saving is $r$. The household will live to age $\mathrm{T}$ and dies with no wealth. Then the lifetime budget constraint is:

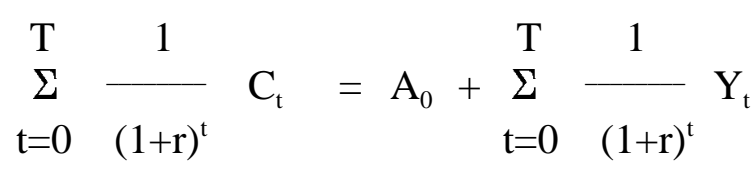

Current consumption will be chosen to maximize discounted utility subject to the budget constraint. Assuming that utility is logarithmic and the discount rate is $\delta$, the sum of discounted utilities is

$$
\underset{\mathrm{t}=0}{\sum} \delta^{\mathrm{t}} \log \left(\mathrm{C}_{\mathrm{t}}\right)
$$

Maximizing (2) with respect to (1) yields:

$$
\mathrm{C}_{\mathrm{t}}^{*}=\frac{\delta^{\mathrm{t}}(1+\mathrm{r})^{\mathrm{t}}}{\sum_{\mathrm{t}=0}^{\mathrm{T}} \delta^{\mathrm{t}}(1+\mathrm{r})^{\mathrm{t}}}\left[\mathrm{A}_{0}+\sum_{\mathrm{t}=0}^{\mathrm{T}} \stackrel{1}{(1+\mathrm{r})^{\mathrm{t}}} \mathrm{Y}_{\mathrm{t}}\right]=m_{\mathrm{t}} \mathrm{V}
$$


where $\mathrm{V}$ is the sum of initial assets and the present discounted value of labor income. The basic insight from the lifecycle model is that an unanticipated increase in the value of assets, $\Delta \mathrm{A}_{0}$, would raise spending over the lifetime, with the increase in period $\mathrm{t}$ given by $m_{\mathrm{t}} \Delta \mathrm{A}_{0}$. The marginal propensity to consume, $m_{\mathrm{t}}$, would be relatively small for a household at an early stage in the lifecycle, but becomes larger as the lifecycle goes on.

The simple formulation abstracts from some issues that may be relevant for understanding the effects of wealth on consumption. The first concerns uncertainty: If labor income, rates of return, and/or lifespan are uncertain, an increase in the value of household resources may not be used to boost spending evenly over the remaining lifetime, but rather may be used to build up precautionary balances against future consumption shocks (Deaton 1991, Carroll 1992, Davies 1981). Second, households need not die without wealth, but can leave bequests. Indeed, tax provisions strongly favor bequests in the form of stock, so if bequest motives play a role in stockholders' saving decisions, their response to wealth gains may partly reflect such concerns. ${ }^{1}$ A third and related question is whether the lifecycle model, even if augmented by bequests, adequately captures the behavior of wealthy households--an important consideration because this group owns a lion's share of household stock. For example, Carroll (1997) has argued that very wealthy households may value the accumulation of wealth as an end in itself. Finally, households may view wealth changes as something other than one-time shocks expected to persist indefinitely: for example, a period of unusually high returns may be seen as temporary, and likely to be followed by low returns, making the prediction for consumption uncertain. ${ }^{2}$

Most empirical research on the wealth effect has investigated the response of aggregate consumption to changes in household wealth. Studies in the consumption-function

1. Capital gains on bequeathed stock are not subject to taxation, although the bequest could be subject to estate taxes; see Poterba (1997) for further discussion. Recent studies on the importance of bequest motives include Wilhelm (1996) and Laitner and Juster (1996).

2. Theoretically, an unexpected rise in $r$ has an ambiguous effect on saving: the substitution effect would encourage saving, but the income effect, reinforced by a revaluation of human and financial wealth, would discourage it. Note also that the simple model ignores portfolio aspects of households' decisions; for example, a rise in stock wealth may be due to a decline in the interest rate, which would affect consumption directly. 
tradition found a marginal propensity to consume (mpc) out of stock market wealth of 0.03 to 0.07 , with the effect materializing over one to three years. ${ }^{3}$ More modern macroeconometric models also find a significant effect of stock market wealth on spending, with estimates of the mpc on the lower end of the traditional range. ${ }^{4}$ Most estimates of the mpc are quite consistent with the simple lifecycle model. For example, in the simple model above, if $\delta=1 /(1+\mathrm{r})$ and there are $\mathrm{T}$ years of life remaining, an unanticipated $\$ 1$ increase in assets would raise spending by $1 / \mathrm{T}$. With the average age of stockholders just under 50 and their average life expectancy around 80 , the implied mpc would be around 0.033 --quite close to recent macroeconometric estimates. ${ }^{5}$ A significant effect of stock prices on aggregate spending also appears in studies using an Euler-equation approach: notably, Hall (1978) found that lagged stock prices were useful for predicting changes in consumer spending, in apparent violation of the rational expectations lifecycle/permanent income hypothesis.

While it seems irrefutable that there would be a wealth effect in the long run, it is possible that the short-run correlation between stock prices and aggregate spending reflects some process other than a reoptimization of spending in response to higher wealth. Previous research documents a role of the stock market as a passive predictor of information. ${ }^{6}$ Thus, stock prices may simply lead aggregate economic activity, with the market anticipating a pick-up in production and employment that eventually translates into higher consumer spending. Consequently, the observed correlation could be statistical, without any short-run change in spending specifically induced by a change in wealth (Poterba and Samwick, 1995). Thus, it would seem important to have micro-level information on consumer spending to disentangle these two stories.

Some studies have used micro data to examine the spending effects of changes in stock market wealth. In an early study, Friend and Lieberman (1975) found a negative

3. For other forms of wealth, the mpc was larger and more immediate. For example, Brayton and Mauskopf (1987) reported an mpc of 0.05 for stock wealth and 0.09 for other types of wealth in the MPS Quarterly Econometric Model. See also Mishkin (1977).

4. In 1996, estimates from the FRB/US quarterly model placed the mpc at 0.03 for stock market wealth and 0.075 for other net wealth (Brayton and Tinsley, 1996, p. 17).

5. Data for this computation come from the 1995 Survey of Consumer Finances.

6. See, for example, Morck, Shleifer, and Vishny (1990). 
relationship between stock price changes and saving, using data from the 1962-63 Survey of Financial Characteristics of Consumers. Research using the Panel Study of Income Dynamics suggests the consumption of stockholders is more highly correlated with stock returns than the consumption of nonstockholders (Mankiw and Zeldes 1991, Poterba and Samwick 1995). Poterba and Samwick (1995) investigated whether spending on items bought disproportionately by high-income households--who own a large share of household stock-rose disportionately when stock prices increased. While they found some effect of stock prices on new vehicle sales, the effect was not significant for upper-luxury vehicles, making it hard to rule out the "leading indicator" view.

Some analysts have suggested that changing patterns of stock ownership have altered relationships between wealth gains and spending. As shown in Table 1, the share of households owning stock in some form rose from 31.6 percent in 1989 to 40.3 percent in $1995 .^{7}$ Much of this expansion took place through mutual funds and retirement accounts: direct ownership of shares actually edged down over this period. Conceivably, the rise in stockownership may have altered the sensitivity of aggregate spending to changes in wealth, for example, by shifting wealth away from groups with relatively low marginal propensities to consume. ${ }^{8}$ However, the evidence on whether ownership has become less concentrated is really rather mixed: for example, between 1989 and 1995, there was an appreciable decline in the share of stock held by households with incomes in the top 5 percent, but the share of stock owned by households in the top 5 percent of the wealth distribution actually rose a bit (see Table 2). ${ }^{9}$ Certainly, it remains true that a large share of wealth gains accrues to a narrow sement of the population.

Along with the expansion of ownership has been a shift toward holdings in taxdeferred retirement accounts. Whereas stock held in such accounts represented one-fifth of

7. Here "stockownership" includes stock held directly, as well as through mutual funds, 401(k)type retirement accounts, IRA/Keogh accounts, and trusts and other managed assets.

8. Dynan, Skinner, and Zeldes (1997) present some evidence that households with relatively high permanent incomes have relatively low mpc's.

9. Note that findings on the concentration of ownership depend on the measure used. Poterba and Samwick (1995) looked at the share of stock wealth owned by the top $1 / 2$ percent of stockholders, finding that it declined between 1983 and 1992. 
household equity in 1989, this figure had increased to one-third by 1995 (see Table 1). Some analysts have suggested that the shift toward retirement accounts has reduced the sensitivity of consumption to stock price gains. Gains accruing in such accounts are often fairly illiquid, with taxes, penalties and/or limits applying to withdrawals. Yet the ability to borrow against retirement accounts, along with the basic fungibility of household finances, means that wealth gains can be spent without liquidating holdings. Alternatively, in "mental accounting" views of saving, households overcome self-control problems by saving into special retirement accounts that they consider to be off-limits; in this case, households may simply ignore wealth gains accruing in such accounts (Shefrin and Thaler 1988; Thaler 1994). Poterba and Samwick (1995) present some evidence in this regard: compared to stockholders with directly-held shares, the correlation between consumption and stock returns was lower for stockholders having only retirement accounts. However, the lower correlation may reflect other differences between the two groups: for example, retirement accounts represent a relatively small share of the stockholdings of high-income households and of older households, whose spending may anyway be more sensitive to changes in stock prices.

\section{The Michigan SRC Survey of Consumers}

To investigate the influence of rising stock prices on consumer spending, the Federal Reserve Board sponsored a special set of questions on the University of Michigan SRC Survey of Consumers, an ongoing, nationally representative survey of U.S. households. The survey interviews about 500 households by telephone each month. ${ }^{10}$ In addition to the core questions on attitudes and expectations, the survey collects information on household characteristics and various special topics. ${ }^{11}$ The surveys conducted in 1997 included questions on financial assets that could be used to identify households owning stock in some form, including individual stocks, mutual funds, 401(k) retirement accounts, and IRA/Keogh accounts.

10. See Curtin (1995) for a detailed description of the survey's methodology.

11. The core questions are used to compute the Index of Consumer Sentiment. Shapiro and Slemrod (1995) used data from the Michigan Survey to study consumer response to a change in tax withholding. 
From July to September of 1997, the Michigan Survey interviewed 1,500 households, of whom 592 households reported owning stock in some form. The stockowning households were asked a special set of questions about saving and spending. ${ }^{12}$ The questions were largely qualitative, reflecting the difficulty of collecting detailed financial information in a relatively brief phone interview. Nonetheless, the data from the Michigan Survey seem to provide a reasonably good representation of U.S. stockholders. According to the Michigan Survey, about 35.4 percent of households owned stock in one of the above-mentioned forms-not far below a comparable figure of 39.8 percent from the 1995 Survey of Consumer Finances. In terms of the value of holdings, the total value of stock reported by Michigan Survey respondents was $\$ 4.4$ trillion--about 75 percent of the Flow of Funds estimate of $\$ 5.9$ trillion for the stockholdings of households in 1997:Q2. ${ }^{13}$ However, 21.6 percent of stockholders in the Michigan Survey did not report a dollar value of their holdings; if missing values are imputed using a standard regression approach, the total would rise to $\$ 5.3$ trillion, or 90 percent of the Flow of Funds estimate. ${ }^{14}$ Thus, the data from the Michigan Survey appear to provide a reasonably good portrayal of household stockownership and stock wealth. ${ }^{15}$

\section{Results from the Michigan Survey}

12. Richard Curtin of the SRC provided very valuable advice and support in the design and pretest of the questions.

13. The Flow of Funds figures reported here include directly held equities and equities held through mutual funds and defined contribution pension plans; they exclude equity in closely held corporations. (Equities held by nonprofit organizations are also excluded). In the Michigan Survey, respondents were asked the question, "Considering all of your (family's) investments in the stock market, including individually held stocks, stocks in mutual funds, stocks in 401(k) retirement accounts, and stocks held in IRA/Keogh accounts, overall about how much would your investments be worth today?" Conceivably, reported values may include nonstock items held in diversified assets (like "balanced" mutual funds).

14. Note that 2.5 percent of stockholders said their holdings were worth more than $\$ 100,000$ but did not provide an upper bound; for households in this group, I set their holdings equal to $\$ 250,000$-the median of the weighted distribution of reported values above $\$ 100,000$.

15. In comparison, the 1995 SCF showed a total value of stock of $\$ 3.8$ trillion, versus $\$ 3.9$ trillion in the Flow of Funds for 1995:Q3. Unlike the Michigan Survey, the SCF oversamples wealth households to ensure their adequate representation. 
Households owning stock were asked "Have you [has your family] changed the amount of money you spend or save as a result of the trend in stock prices during the past few years?" If they said yes, they were asked how their spending and saving had changed, and their responses were recorded verbatim. The open-ended approach allowed households to report any response they thought was relevant; however, because the question provides little structure and the effects of higher wealth may be hard to distinguish from other determinants of spending, there could be some tendency for changes to be misreported.

Table 3 reports the distribution of responses to the wealth-effect questions. Surprisingly, the vast majority of respondents--85 percent--said the recent trend in stock prices had not affected their spending or saving. Only 3.4 percent of stockholders said they had increased their spending or lowering their saving as a result of higher stock prices-including such responses as "bought a car", "bought a house", and "took more vacations"-while 11.6 percent of stockholders said the trend in stock prices had caused them to save more. Of course, the open-ended questions leave respondents free to use their own terminology, which tends to blur the distinction between the "saved more" and "saved less" responses. ${ }^{16}$ Nonetheless, the fact remains that very few respondents reported any appreciable change in spending or saving in response to the trend in stock prices.

These results are unexpected, considering the large increase in household wealth over the past few years. A possible explanation is that respondents underreported changes that were modest in magnitude. For example, the median stockholder in the Michigan survey had holdings worth $\$ 46,500$; assuming the value rose at the same rate as the S\&P 500 , it would have increased $\$ 23,500$ between 1994 and 1997. With an mpc of 0.03 and typical assumptions about lags, this increase in wealth would be expected to generate an extra $\$ 700$ in spending, phasing in over the six-year period from 1994 to 2000 . An effect of this magnitude may not be perceived or reported by individual respondents, yet may show up as a significant effect in the aggregate data.

Some evidence in favor of this interpretation comes from respondents' frequent

16. Notably, some of the respondents saying they "saved more" apparently included capital gains as saving--i.e. their holdings rose in value, but they did not fully spend the gains. 
mentions of long-term saving goals in explaining their spending and saving behavior. For example, when asked about their reasons for saving, the most common reason given by stockholders was "retirement", with almost one-half of respondents citing this as their main reason for saving. ${ }^{17}$ The survey also asked stockholders whether, in the next 12 months, they planned to liquidate assets to make purchases, or to lower their saving. About 70 percent of stockholders said they had no plans to liquidate assets or to save less in the next year. When asked to explain their reasons, again the most common explanation was "saving for retirement," mentioned by 45 percent of those not planning to liquidate assets or lower saving; another 33.9 percent gave a general response along the lines of "don't need the money right now" (see Table 4). In other words, respondents commonly seemed to view stock gains as part of long-term saving, with few immediate implications for spending.

Is there any evidence that the accrual of gains in retirement accounts had a restraining effect on spending? Not particularly. For example, about 55 percent of stockholders reported that their holdings were mostly in retirement accounts; compared to other stockholders, this group was not less likely to report an increase in spending due to the trend in stock prices. Also, of those saying they had no plans to liquidate assets or increase spending in the next year, only 9.7 percent specifically mentioned that their savings were locked up in illiquid forms (Table 4). Thus, the data do not point to any central role of retirement accounts in the modest reported effects.

Table 5 presents some cross-tabulations for responses to the questions on the wealth effect. Three findings are of interest. First, it has been suggested that concerns about stock price reversals kept stockholders from spending their gains. The survey data suggest that such concerns were not particularly widespread: only 16 percent of stockholders said they thought stock prices would decline in the next year. ${ }^{18}$ Moreover, stock price expectations were not correlated with reported effects of wealth on spending in the past few years. Price

17. Other widely mentioned factors included precautionary reasons (unemployment, illness, emergencies, and "rainy days"), mentioned by 38 percent of respondents; children's education (19.6 percent), major purchases (17 percent), and investments ( 9 percent).

18. In readings from the Conference Board's consumer surveys for the same months, 18 to 19 percent of households expected stock prices to decline in the next year. 
expectations were correlated with plans to liquidate assets to make a purchase or to reduce saving in the next year, but in an unexpected way: compared to other stockholders, those expecting prices to fall were more likely to plan to liquidate assets or lower saving in the next year. While not theoretically inconsistent, it seems inadvisable to overinterpret this result; for example, stock price expectations have no significant effect when other determinants of spending are taken into account (see below).

Second, with much of the rise in stock market wealth likely accruing to wealthier stockowners, the behavior of this group is of particular interest. Indeed, the Michigan Survey data show some significant variation in spending and saving behavior related to the value of holdings. In particular, stockholders with holdings above $\$ 250,000$--roughly the top 10 percent--were significantly more likely to report an effect of stock price trends on their spending or saving in the past few years. The share is still fairly modest, with only 12.6 percent of this group reporting a positive effect. But the positive association is generally consistent with the view that wealthy households play an influential role in the aggregate wealth effect.

Third, uncertainty about future income may also influence decisions about spending or saving wealth gains. Indeed, during the current economic expansion, there has been much discussion of "job insecurity"--the perception that involuntary job loss is more common, or more broadly distributed, than it was in the past (Greenspan 1997, Farber 1997). Concerns about job security could affect stockholders' willingness to spend wealth gains: if they perceive a nonnegligible risk of job loss and save partly for precautionary reasons, they may be inclined to let wealth gains accumulate as a buffer against consumption shocks, rather than notch up their spending. To gain some insight into this issue, the Michigan Survey asked stockholders, "During the next 5 years, what do you think the chances are that you (or your husband/wife) will lose a job you wanted to keep?"19 Respondents reported appreciable risks of job loss: the mean percent-chance of a job loss was 20 percent, and the median was 10

19. Lusardi (1998) analyzes responses to a similar question asked in the Health and Retirement Survey. See Dominitz and Manski (1997) on the advantages of asking expectations questions in a probabilistic format. 
percent. ${ }^{20}$ However, there was no significant cross-section variation between the perceived risk of job loss and reported spending and saving behavior. The survey asked similar questions about other sources of uncertainty--including prospects for income growth in the next five years, the chance of living to age 75 , and adequacy of pension and Social Security income for maintaining living standards in retirement--but here too there was no significant correlation with spending and saving behavior.

Multivariate analysis. To examine reported spending and saving behavior further, I also ran probit analyses using three measures of spending-effects as dependent variables: (a) whether the respondent reported higher spending or lower saving due to the trend in stock prices in the past few years, (b) whether the respondent reported any effect of the trend on saving or spending in the past few years, and (c) whether the household planned to liquidate assets to make purchases or to lower saving in the next 12 months. The explanatory variables were the respondent's age and education, household income, and dummy variables indicating the following: whether the household's holdings were mostly in retirement accounts, whether they expected stock prices to decline in the next year, whether their holdings were worth $\$ 250,000$ or more (approximately the top 10 percent), and whether they reported a risk of an involuntary job loss of 30 percent or more. As shown in Table 6, few variables had statistically significant effects, and the explanatory power of the models was low. To some extent, these facts may simply reflect the limitations of the data, including the small sample size and the possibility of misreporting of the dependent variables; they also indicate the usefulness of reinvestigating this issue using other data sources. Nonetheless, a finding of interest concerns the association between large holdings and effects on spending: households with holdings of $\$ 250,000$ or more were significantly more likely to report an effect of wealth on spending in the past few years. ${ }^{21}$ This is consistent with the descriptive results and suggests an importance of this group's behavior in the aggregate wealth effect.

20. A 10-20 percent chance over a five-year period is consistent with a 2-4 percent chance per year. Using data from a University of Wisconsin survey, Dominitz and Manksi (1997) report a relatively good correspondence between expected and actual risks of job loss.

21. Results were qualitatively similar using a cut-off of $\$ 500,000$ (the top 5 percent); indeed, this variable was also statistically significant in the probit for spending plans in the next year, although at a 10 percent level only. 


\section{Concluding remarks}

In sum, while the vast majority of stockholders reported no appreciable effect of stock prices on their spending or saving, the results of the Michigan Survey are broadly consistent with lifecycle saving and a modest wealth effect. Specifically, the lifecycle view predicts only modest effects of wealth gains on current spending, as spending gains would be distributed over the household's lifetime. Although it is possible that the modest reported effects reflect myopia, mental accounting, or just misreporting, the fact that many stockholders mentioned "retirement saving" in explaining their behavior provides some reasonable support to the lifecycle view. Moreover, very few stockholders specifically mentioned the accrual of gains in retirement accounts as a constraint on their spending.

At the same time, the survey data point to more appreciable effects of wealth on spending for stockowners with large holdings. This lends support to Poterba and Samwick's (1995) approach to the aggregate wealth effect, and squares well with reports of strong spending at high-end retailers during the 1990 s stock boom. ${ }^{22}$ More broadly, the finding also suggests a need to improve our understanding of the saving and spending decisions of wealthy households. The distribution of spending is not as concentrated as the distribution of wealth, but the spending of well-off households is still disproportionate: for example, in 1995, households in the top 20 percent of the income distribution accounted for 37 percent of total spending. ${ }^{23}$ Some recent studies suggest that the saving behavior of wealthy households may not be well-described by standard versions of the lifecycle model. ${ }^{24}$ Our work on the wealth effect suggests that, for understanding the behavior of aggregate consumption, this question may matter more than has traditionally been assumed.

22. See, for example, "Hot Sales at the High End," Washington Post, 1/26/97, p. H1.

23. Figures from "Average annual expenditures, by quintiles of income before taxes, $1995^{\prime}$ Consumer Expenditure Survey, Bureau of Labor Statistics. Data from 1984 to 1995 indicate little variation in this share from year to year.

24. Dynan, Skinner, and Zeldes (1997) present evidence that wealthy households save more than standard models would predict, and suggest a role of bequest motives. Carroll (1997) argues that very wealthy households value wealth for its own sake, perhaps for the status or influence it confers. 


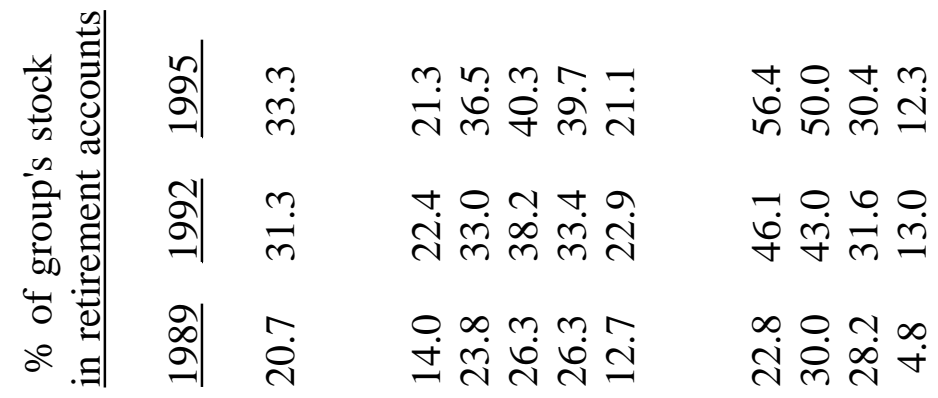

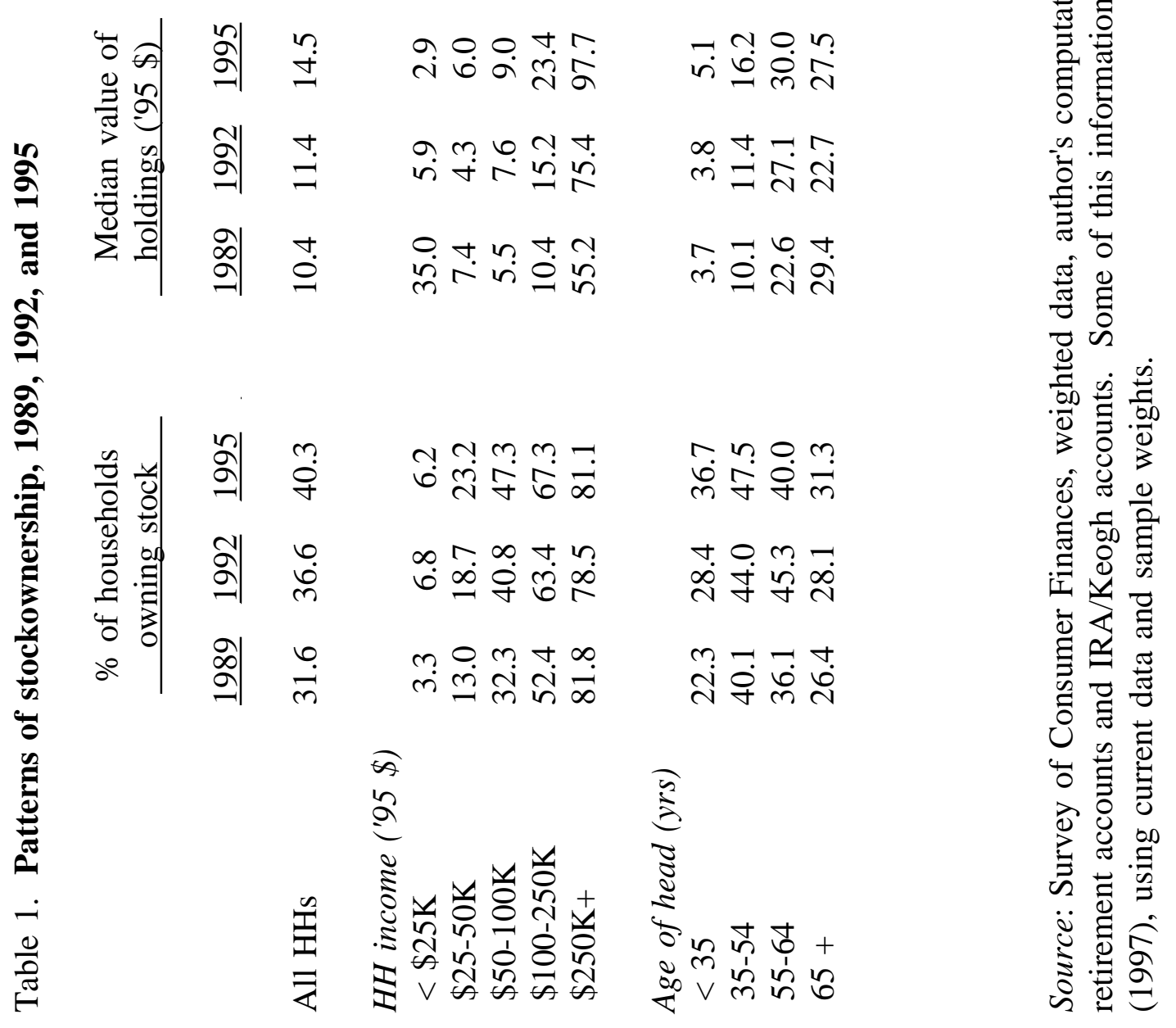


Table 2. Distribution of stockownership, 1989, 1992, and 1995

Share of household stock owned by each group

$\begin{array}{lccc} & \underline{1989} & \underline{1992} & \underline{1995} \\ \text { All HHs } & 100 & 100 & 100 \\ & & & \\ \begin{array}{l}\text { By HH income } \\ \text { (percentile): }\end{array} & & & \\ \text { Bottom 25 } & 1.3 & 1.2 & 1.6 \\ \text { 25-49 } & 4.0 & 3.8 & 6.4 \\ \text { 50-74 } & 10.9 & 12.6 & 11.5 \\ 75-89 & 14.8 & 16.5 & 19.4 \\ 90-94 & 11.3 & 14.7 & 10.8 \\ \text { Top 5 } & 57.6 & 51.2 & 50.3 \\ & & & \\ \text { By net worth } & & & \\ \text { (percentile): } & & & \\ \text { Bottom 25 } & 0.1 & 0.2 & 0.3 \\ 25-49 & 1.6 & 1.6 & 1.9 \\ \text { 50-74 } & 4.9 & 7.1 & 6.4 \\ 75-89 & 16.5 & 14.0 & 11.4 \\ 90-94 & 11.5 & 11.6 & 12.2 \\ \text { Top 5 } & 65.5 & 65.6 & 67.9 \\ & & & \end{array}$

By age of head

(years):

$\begin{array}{lrrr}<35 & 4.7 & 4.2 & 3.9 \\ 35-54 & 39.2 & 38.9 & 39.9 \\ 55-64 & 22.1 & 28.0 & 23.5 \\ 65+ & 34.0 & 28.8 & 32.7\end{array}$

Source: Survey of Consumer Finances, weighted data, author's computations. 
Table 3. Reported effects of trends in stock prices on saving and spending in the past few years

\section{$\underline{\text { Reported effect }}$}

No effect

Spend more/save less

Not specified

Bought a car

Bought a house

Gave more to charity

Took more vacations

Spend less/save more

Not specified

Invested in stock market

Increased 401(k) contributions

Increased mortgage payments
Percent of stockowners

reporting each effect

85.0

3.4

2.6

0.4

0.1

0.1

0.1

11.6

7.2

3.3

0.7

0.4

Note: Stockowning households were asked, "Have you [has your family] changed the amount of money you spend or save as a result of the trend in stock prices during the past few years?" If yes, they were asked, "How has your spending or saving changed?" and the response was recorded verbatim. 
Table 4. Reasons for not liquidating assets or lowering saving in the next 12 months

Reason for not liquidating assets or lowering saving

Saving for retirement

Don't need the money right now

Saving for precautionary reasons

Illiquidity of gains

Saving for major purchase

Saving for education

Saving to buy a home
Percent of stockowners with no plans to liquidate

assets or lower saving

Notes: Figures are computed for the 69.5 percent of stockholders reporting no plans to liquidate assets or lower saving in the next 12 months. Respondents could give more than one reason. The category "illiquidity of gains" includes "cannot withdraw till retirement", "would have to pay taxes on money", "would have to pay penalties for early withdrawal", and "would lose interest if withdrew money early." 


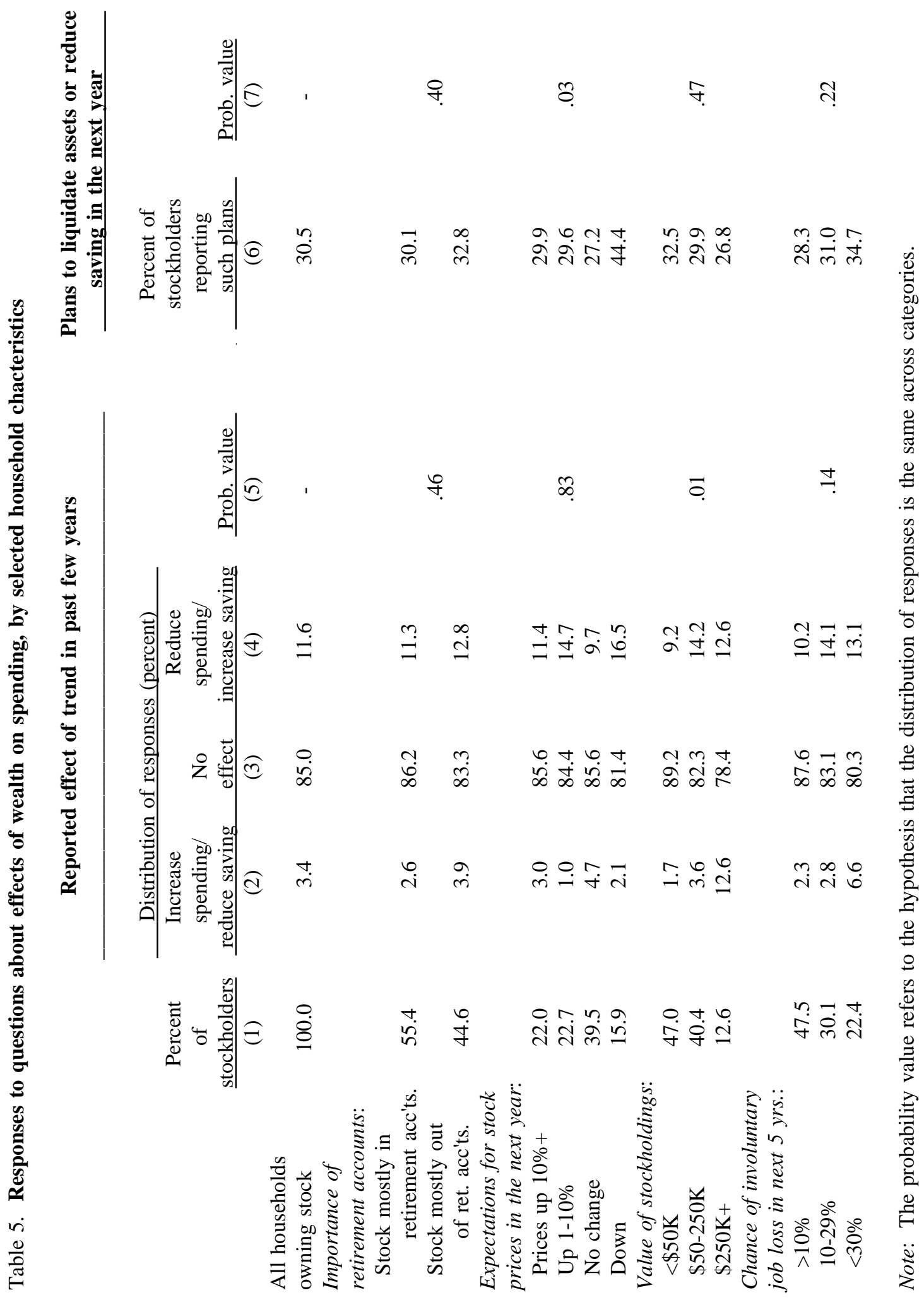




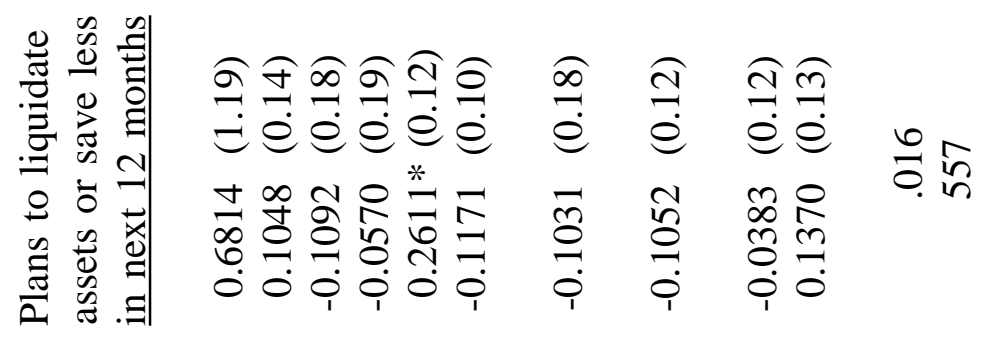

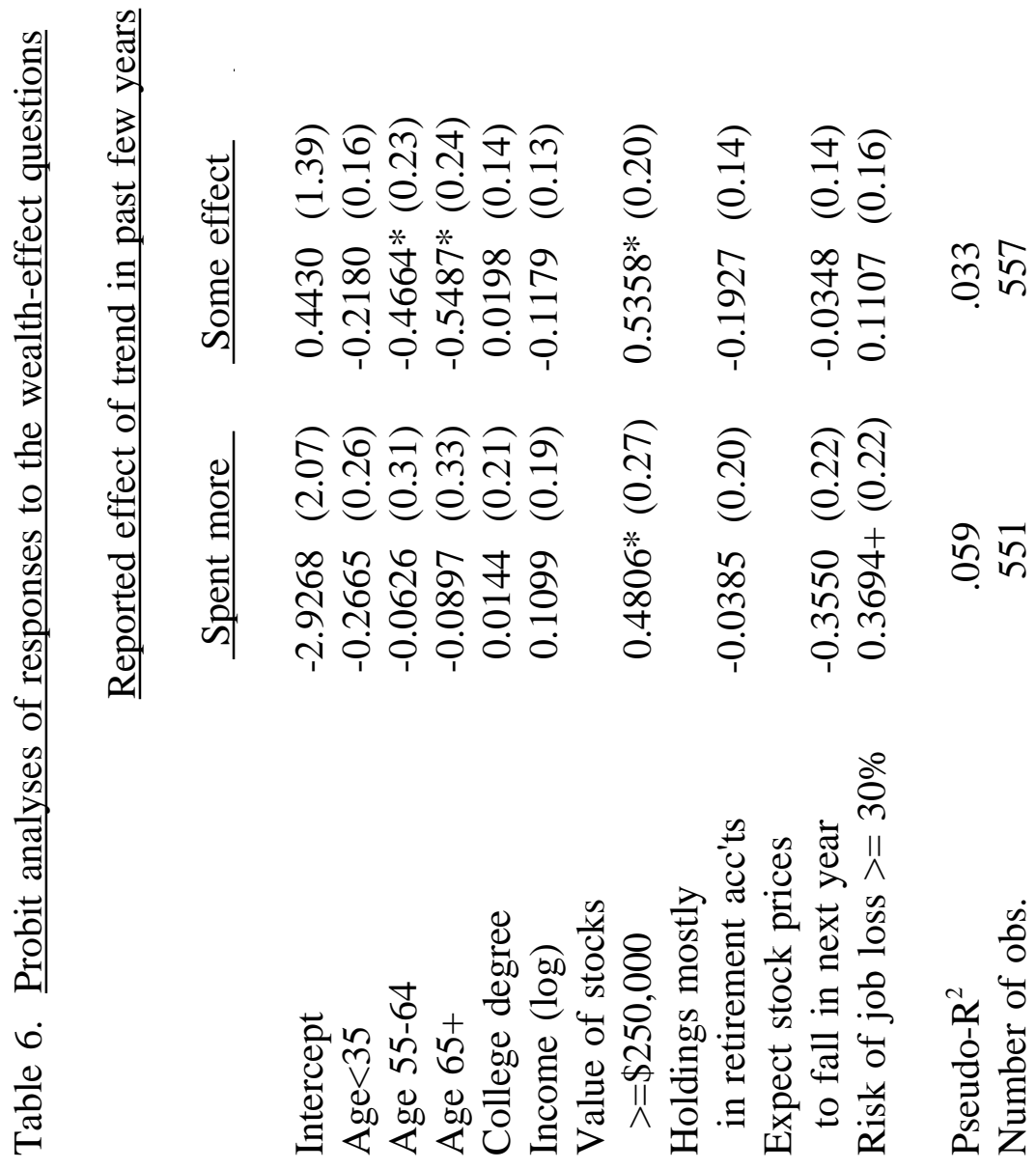




\section{REFERENCES}

Blume, Marshall, and Stephen P. Zeldes (1994). "Household Stockownership Patterns and Aggregate Asset Pricing Theories." Mimeo, Wharton School.

Brayton, Flint, and Eileen Mauskopf (1987). "Structure and Uses of the MPS Quarterly Econometric Model of the United States," Federal Reserve Bulletin, Vol. xx, No. x (February), pp. 93-109. , and Peter Tinsley, eds. (1996). "A Guide to the FRB/US: A Macroeconomic Model of the United States." Federal Reserve Board, FEDS Working Paper No. 1996-42.

Carroll, Christopher D. (1992). "The Buffer-Stock Theory of Saving: Some Macroeconomic Evidence," Brookings Papers on Economic Activity, No. 2, pp. 61-156. (1997). "Why Do the Rich Save So Much?" Paper presented at Michigan Tax conference, October.

Curtin, Richard (1995). "Surveys of Consumers." Mimeo, University of Michigan, Survey Research Center.

Davies, James B. (1981). "Uncertain Lifetime, Consumption, and Dissaving in Retirement," Journal of Political Economy, Vol. 89, No. 3, pp. 561-577.

Deaton, Angus (1991). "Saving and Liquidity Constraints," Econometrica, Vol. 59, pp. 12211248.

Dominitz, Jeffrey, and Charles Manski (1997). "Perceptions of Economic Insecurity: Evidence from the Survey of Economic Expectations," Public Opinion Quarterly, Vol. 61, pp. 265-291.

Dynan, Karen, Jonathan Skinner, and Stephen P. Zeldes (1997). "Do the Rich Save More?" Mimeo.

Farber, Henry (1997). "The Changing Face of Job Loss in the United States, 1981-1995," Brookings Papers on Economic Activity, Microeconomics, pp. 55-142.

Friend, Irwin, and Charles Lieberman (1975). "Short-Run Asset Effects on Household Saving and Consumption: The Cross-Section Evidence," American Economic Review, Vol. 
65, No. 4 (September), pp. 624-633.

Greenspan, Alan (1997). "Monetary Policy Testimony and Report to the Congress," Humphrey-Hawkins Report before the Committee on Banking, Housing, and Urban Affairs (February).

Ha1l, Robert E. (1978). "Stochastic Implications of the Life Cycle-Permanent Income Hypothesis: Theory and Evidence," Journal of Political Economy, Vol. 86, No. 6, pp. 971-987.

Kennicke11, Arthur B., Martha Starr-McCluer, and Annika E. Sunden (1997). "Family Finances in the U.S.: Recent Evidence from the Survey of Consumer Finances," Federal Reserve Bulletin, Vol. 83, No. 1 (January), pp. 1-14.

Laitner, John and F. Thomas Juster (1996). "New Evidence on Altruism: A Study of TIAACREF Retirees," American Economic Review, Vol. 86, No. 4 (September), pp. 893908.

Lusardi, Annamaria (1998). "On the Importance of the Precautionary Saving Motive," American Economic Review, forthcoming, May 1998.

Mankiw, Gregory, and Stephen P. Zeldes (1991). "The Consumption of Stockholders and Nonstockholders," Journal of Financial Economics, Vol. 29, No. 1, pp. 97-112.

Mishkin, Frederic S. (1977). "What Depressed the Consumer? The Household Balance Sheet and the 1973-75 Recession," Brookings Papers on Economic Activity, 1:1977, pp. 123164.

Morck, Randa11, Andrei Schleifer, and Robert W. Vishny (1990). "The Stock Market and Investment: Is the Market a Sideshow?" Brookings Papers on Economic Activity, No. 2, pp. 157-202.

Poterba, James (1997). "The Estate Tax and After-Tax Investment Returns." NBER Working Paper No. 6337 (December). and Andrew Samwick (1995). "Stock Ownership Patterns, Stock Market Fluctuations, and Consumption," Brookings Papers on Economic Activity, No. 2, pp. 295-372.

Shapiro, Matthew, and Joel Slemrod (1995). "Consumer Response to the Timing of Income: 
Evidence from a Change in Tax Withholding," American Economic Review, Vol. 85, No. 1 (March), pp. 274-283.

Shefrin, Hersh M. and Richard T. Thaler (1988). "The Behavioral Life-Cycle Hypothesis," Economic Inquiry, Vol. 26, No. 4 (October), pp. 609-643.

Thaler, Richard T. (1994). "Psychology and Savings Policies," American Economic Review, Vol. 84, No. 2 (May), pp. 186-192.

Wilhelm, Mark O. (1996). "Bequest Behavior and the Effect of Heirs' Earnings: Testing the Altruistic Model of Bequests," American Economic Review, Vol. 86, No. 4 (September), pp. 874-892. 